\title{
ANDEAN ICEFIELDS TO AMAZONIAN JUNGLES: A RADICAL NEW VIEW OF THE LATE PLEISTOCENE OF SOUTH AMERICA
}

K.E.Campbell Jr. ${ }^{1}$

\section{ABSTRACT}

Late Pleistocene glaciation in the Altiplano of the Central Andes was far more extensive than previously recognized, with all of the northern Altiplano being covered by a glacial icecap. Large paleolakes existed in the Altiplano, but their relationship with glacial episodes is unclear. One Altiplano paleolake filled the basin to the $4,100 \pm m$ contour drained catastrophically through the Achocalla Valley of Bolivia approximately 45,000-40,000 years B.P. The catastrophic floodwaters flowed north and south upon reaching the lowlands of eastern Bolivia, scouring much of lowland Amazônia and depositing the Belterra Clay. Asymmetric ripplemarks on the Amazon Cone record the passing of the floodwaters into the Atlantic Ocean. The Belterra Clay dammed the eastern outlet of the Amazon drainage to an elevation of $260 \pm m$, resulting in the formation of a great freshwater lake, Lake Amazonas. Lake Amazonas accumulated vast quantities of fine-grained sediments through deposition in basin-wide "birds's foot" deltas before it began draining eastward about 13,500 years B.P. Except for minor drainage system refinements, the Amazon Basin had assumed its current physical parameters by 6,000 years B.P. Paleolakes may have covered the Altiplano up to the $3,950 \pm m$ contour in the early Holocene, desiccating to form the modem lakes and salares only in the late Holocene. The geological, biological and climatological ramifications of the Altiplano glaciation and paleolakes, the catastrophic flood and the formation, filling and draining of Lake Amazonas are enormous.

\section{INTRODUCTION}

\footnotetext{
${ }^{1}$ Natural History Museum of Los Angeles County, 900 Exposition Blvd., Los Angeles, California 90007 USA.
} 
The Amazon Basin and its biota are an extremely important, large, multi-faceted ecosystem and, as wilderness areas around the world disappear, the impending loss of this ecosystem is focusing attention on it as never before. As awareness of the importance of the Amazonian ecosystem increases, so too does the realization that very little is known of the geological history of the Amazon Basin and surrounding physiographic provinces.

Interest began focusing on Amazônia as an unstable forest ecosystem following the presentation by HAFFER (1969) of his "Quaternary refuge theory." See DUELMAN (1979), PRANCE (1982) and WHITMORE \& PRANCE (1987) for papers on various aspects of the refuge theory. Unfortunately, most analyses of the refuge theory in these and other works were based on interpretations of blological or climatological data, with little or no supporting geological data. This paper will not argue the case for or against the refuge theory. It will instead present the argument that the refuge theory as originally proposed is irrelevant to an understanding of the biogeography of lowland Amazônia.

CAMPBEL \& FRAILEY (1984) described geological deposits in southwestern Amazônia, proposed massive, seasonal Holocene flooding as a mechanism for their origin and suggested that the exceptionally high biological diversity in the area could be explained by conceptualizing the region as an "island" in a state of supersaturated equilibrium. Later, CAMPBEL et al. (1985) described deposits along the Rio Beni, Bolivia, and correlated these deposits with those described by CAMPBE丩 \& FRAILEY (1984). CAMPBELL et al. (1985) proposed that a catastrophic flood resulting from the draining of a paleolake covering the Altiplano of Bolivia and Peru contributed to the formation of these deposits. CAMPBEL \& ROMERO (1987, in press) described geological deposits in southeastern Peru, correlated these deposits with those described by CAMPBEL \& FRALEY (1984) and CAMPBEL et al. (1985), presented radiocarbon dates of about 36,500 years B.P. for basal horizons of the deposits and suggested that the overall composition of the deposits indicated deposition within a complex delta system in a large lake that existed in the region until about 12,500 years B.P.

FRAILEY et al. (in press) described geological deposits in western Brazil as deltaic deposits that formed in a large lake that covered primarily western Amazônia, which they termed Lake Amazonas. They correlated these deposits with those described by CAMPBEL \& FRALEY (1984), CAMPBEL et al. (1985) and CAMPBEL \& ROMERO (1987, in press), and hypothesized that Andean tectonism caused downwarping of the western edge of the Amazon Basin, providing a sub-basin within which Lake Amazonas formed. They interpreted a lake margin within the Amazon Basin at the $150 \mathrm{~m}$ contour, suggesting that post-depositional isostatic adjustment lifted the deltaic deposits of the southwestern portion of the basin to their current elevations, which are about $250 \mathrm{~m}$.

Recent reviews of Quaternary paleoecological data from the Amazon Basin by COLINVAUX (1987 a, b) have served to demonstrate how very few such data are available, and how most of those that do exist pertain to the latest Holocene. The absence of data from the Pleistocene of the vast 
Amazon Basin, with all of its different subregions, is remarkable and is in itself a hint of something unusual. This paper is intended as a summary of radical, new hypotheses regarding geological events of enormous scale that occurred in South America during the late Pleistocene. Space limitations do not allow the detailed presentation of all supporting data or illustrations, which will come in later papers.

\section{THE CENTRAL ANDES: GLACIATION AND PALEOLAKES}

The Eastern and Western Cordilleras of the Andes are separated in southern Peru and Bolvia by an endorheic basin termed the Altiplano. The Altiplano is approximately $1,000 \mathrm{~km}$ long $250 \mathrm{~km}$ in greatest breadth. Its upper elevation is generally placed at the $4,000 \mathrm{~m}$ contour, which encompasses an area of $140,000 \mathrm{~km}^{2}$, and its lowest point lies at $3,660 \mathrm{~m}$, within the Salar de Uyuni.

The glacial history of the Central Andes, specifically the Altiplano, is very poorly known, despite the impression given in the literature (CLAPPERTON, 1981, 1983; HASTENRATH \& KUTZBACH, 1985 and LAVENU et al., 1984). It is widely assumed, for example, that glaciers from the Eastern Cordillera did not extend lower than the 4,000 m contour on their western slopes. CAMPBEL (in press), however, has demostrated that at least the northern Altiplano was glaciated, citing glacial erratics, till, ice-scoured bedrock, a very youthful drainage system and drumlinoid topographic features as evidence. Striated glacial erratics found on isolated summits on the Altiplano indicate that glacial ice was over $\mathbf{3 0 0} \mathrm{m}$ thick near the southern end of Lake Titicaca.

The extent of the ice cover over the Altiplano is still to be determined, but I predict that eventually the entire Altiplano will be shown to have been covered by glacial ice in the early Wisconsinan, with a smaller, regional ice cover in the late Wisconsinan. Although some of the glacial ice cover unquestionably came from the surrounding cordilleras, most of it probably accumulated, and wasted away, in place as a large icecap.

The recognition that the Altiplano may have been completely covered by glacial ice during the last glaciation requires that hypotheses regarding Altiplano paleolakes, which have been recognized for many years (MOON, 1939), be reexamined. Three of these lakes are Lake Ballivian (at 3,850 $\mathrm{m}$ elevation), Lake Minchin (at 3,760 m) and Lake Tauca (at 3,720 m). Two additional paleolakes, Lake Cabana (at 3,900 m) and Lake Mataro (at 3,950 m), have recently been described (LAVENU et al., 1984).

LAVENU et al. (1984) correlated the series of paleolakes with the several Pleistocene glaciations strictly on elevation; i.e., the highest lake level (Lake Mataro) is said to correspond to the recession phase of the first glaciation (Calvario) in Bolivia, the second highest (Lake Cabana) to the recession phase of the second glaciation (Kaluyo), etc. There are no data to support these conclusions. There are also no published data to support, or to negate, the assertion by HASTENRATH \& KUTZBACH 
(1985) that the paleolakes preceded or coincided with periods of maximum glaciation in the neighboring Andes.

Prior arguments about the ages of the paleolakes may prove to be irrelevant, however, as deposits at two recently discovered sites north of La Paz provide evidence that a paleolake may have covered the Altiplano to an elevation of $3960 \pm 10 \mathrm{~m}$ recently as 5,000 years B.P.. This is in direct opposition to the recent proposal by WIRRMANN \& OLVEIRA ALMEIDA (1987) that the level of Lake Titicaca was $50 \mathrm{~m}$ lower than today between 7,700 to 3,650 years B.P.. Several radiocarbon dates of deposits (peat and highly carbonaceous silts) at these new sites suggest an age range of $>36,500$ years B.P. to 4,630 years B.P., with the two sites partially overlapping in age.

These deposits are localized within two valleys that open broadly onto the Altiplano, and within the valleys the deposits are widespread, horizontal and have lateral continuity. They also have internal channeling and other features that may indicate deposition in a regimen of fluctuating lake levels. Analysis of these deposits is currently underway (CAMPBEL \& GRAFF-MEIER, in prep.). These deposits suggest that the Altiplano was covered by a single gigantic lake well into the Holocene. The previously recognized paleolake shorelines either represent still-stands of this lake as it gradually dried out in the late Holocene, leaving only the modern lakes and salares, or earlier paleolakes.

An observation on the wave-cut terraces referred to Lake Minchin (3,760 m elevation) provides additional support for the hypothesis that glacial ice extended well below the $4,000 \mathrm{~m}$ contour within the Altiplano, or alternatively, that Lake Minchin existed contemporaneously with a major glacial episode, or both. At two sites examined, near Lake Poopo and Salar de Uyuni, glacial erratics are quite abundant on the terraces at 3,760 $\mathrm{m}$ (CAMPBEL, in prep.). The rock specimens observed have no relation to the surrounding bedrock and they are commonly flattened on several sides, with triangular shapes commom. Only rare specimens are striated, most striae probably having been worn away in the high energy beach environment.

The only way these rocks could have come to their present location is by ice-rafting. This means that glaciers were calving into the lake, requiring either that lake levels were sufficiently high at some point in time to reach the glaciers, or that the glaciers extended to below the $3,760 \mathrm{~m}$ contour. I propose that both events occurred, although I cannot now suggest when.

\section{THE MEGAFLOOD}

The Achocalla Valley is a large valley cut into the edge of the Altiplano immediately southwest of La Paz. The walls of this valley are primarily vertical cliffs, up to $200 \mathrm{~m}$ in height, and the floor of the valley is undulating, with many small lakes and ponds. The point of lowest elevations on the rim of the 
valley is about $3,965 \mathrm{~m}$, which is the lowest elevation exit from the northern Altiplano and just a little higher than the highest recognized lake deposits mentioned above.

The Achocalla Valley is said to have formed as the result of a gigantic mudslide at about 9,000 years B.P. (DOBROVOLNY, 1962, 1968). Evidence to support this hypothesis, however, is meager. An alternative origin, l.e., that the valley formed as a result of a catastrophic draining of an Altiplano paleolake was proposed by CAMPBEL et al. (1985). Evidence in support of the latter hypothesis includes the facts that the "mudfiow deposits" are regularly stratified throughout, while true mudfiow deposits have no internal stratification, and some horizons have a reversed magnetic polarity, indicating an age of at least 700,000 years. Further, large blocks of volcanic ash are scattered over the surface and the upper layers presumed "mudfiow deposits," but they are not found mixed throughout the stratigraphic column, as would be expected in a mudfiow. The presumed "mudfiow deposits" are, in fact, "in situ" remnants of the Pliocene La Paz Fm.

Preliminary calculations suggest a minimum estimated outflow from the Altiplano through the Achocalla Valley of $10,000 \mathrm{~km}^{3}$ of water. This conservative estimate is almost double the average annual outfiow of the Amazon River and about four times the size of the largest previously recorded flood on Earth. The date of the flood is placed at approximately $45,000-40,000$ years B.P., or sometime during the mid-Wisconsinan interstadial. Support for this age assignment comes from radiocarbon dating of Amazónian deposits, discussed below.

\section{THE LLANOS DE MOXOS}

The Lanos de Moxos are the pampas of eastern Bolvia south of the Amazon forest and north of the Chaco. The pampas are grasslands maintained by long-term, seasonal flooding in a region of extremely low relief. Scattered across the llanos are large numbers of roughly rectilinear lakes, the origin of which has been referred to fracturing and subsidence of sub-surface bedrock (PLAFKER, 1964). In contrast, I propose that the prevailing NNW winds in this region, which are complemented by strong SSE storm winds, established a regular, alternating pattern of wave action in shallow, water-filled basins within the pampas, and that it was wave action that formed and continues to maintain the rectilinear shape of most of these lakes.

In the western llanos, east of Rurrenabaque, are several rectilinear lakes that extend in a remarkably straight line, a line which coincides with the course of the Rio Beni through the last mountain ridge before it enters the llanos. CAMPBEL et al. (1985) suggested that the basins of these lakes formed as a result of the catastrophic megaflood that drained the Altiplano. Channeled through the narrow water gap of the front range of the Andes at Rurrenabaque, the floodwaters would have entered the flat lowlands 
as a powerful, relatively long-term, steady stream of water in the same direction as the long axis of the string of lakes. A comparable, although much smaller, "hydraulic jump" event is recorded for great Missoula floods of the northwestern United States (BAKER \& NUMMEDAL, 1978:79), previously the largest flood events recorded on Earth.

\section{THE FLOOD DEPOSITS}

When the floodwaters spread over the lowlands of eastern Bolivia they probably flowed both north, into the broad Amazon Basin, and south, through Paraguay and northern Argentina before reaching the South Atlantic. Most of the floodwaters probably flowed northward because of the rapid narrowing and increasing elevations of the Lanos de Moxos to the south.

The surface of southwestern Amazônia was scoured by the flood to a depth well into or below the soil profile. At all localities examined along the Rio Madre de Dios in southwestern Amazônia between the Brazilian Shield and the Andes, and at sites along rivers in the state of Acre, Brazil, the contact between the underlying Tertiary deposits and the overlying late Pleistocene deposits is abrupt (SIMPSON \& PAULA COUTO, 1981; CAMPBEL \& FRAILEY, 1984; CAMPBEL et al., 1985; CAMPBELL \& ROMERO, 1987 , in press and CAMPBEL et al., in prep.).

CAMPBEL et al. (1985) named the Acre Conglomerate Member of the Madre de Dios Fm. (= Iñapari Fm.) and suggested that it was formed by the passage of the catastrophic floodwaters. No other possible flood deposits have been recognized in southwestern Amazônia.

There is, however, a widespread deposit in central and eastern Amazônia that may be the largest deposit of the megaflood. This deposit, the Belterra Clay, was originally described by SOMBROEK (1966) as a blanket deposits that covers the flat plateau land of the axial portion of Amazónia, most commonly at an elevation of $150-200 \mathrm{~m}$, but reaching as high as $350 \mathrm{~m}$. SOMBROEK (1966:26) proposed that the Belterra Clay "...was deposited in a huge, shallow lake or sea bay, and that the flow of suspensed material was in an easterly direction." He considered the age of the deposit to be late Pliocene or early Pleistocene.

TRUCKENBRODT \& KOTSCHOUBEY (1981) presented a very detailed study of the Belterra Clay, concluding that the sediments represent reworked lateritic clays deposited by mud flows or sheet floods in an arid environment. They cite the texture of the deposit and presence of fragments of gibbsite, hematite and small clay balls in support of their conclusions. They also cite the fact that hematitic nodules, or "pseudopisólitos", within the deposit have a polished surface, which they attribute to wind polishing. They, too, placed the age of the deposit at late Pliocene or earliest Pleistocene, and make special note of its widespread, regular plateau surface. 
I propose that the Belterra Clay was deposited by the megaflood that drained the Altiplano. In addition to the features of the deposits cited above, the abrupt, undulating contact between the Belterra Clay and underlying deposits noted by TRUCKENBRODT \& KOTSCHOUBEY (1981) is similar to that observed between the Tertiary and late Pleistocene deposits in southwestern Amazônia. Also, SOMBROEK (1966) observed, and very carefully mapped, the presence of regularly spaced and similarly sized "hummocks" that are widespread on the upper surface of the Belterra Clay. He proposed that these "hummocks" were relicts of Pleistocene termite mounds. Their apparent regularity in size and spacing, however, argues against a biologic origin, and I suggest that they formed as ripplemarks during the passing megaflood.

Ripplemarks have also been observed off the mouth of the Amazon River north and south of llha de Marajo (ADAMS et al., 1986). Asymmetric bedforms on the Amazon shelf at 30-35 $\mathrm{m}$ depth have crests parallel to isobaths, stoss side facing landward, wavelengths of 1-40 m and heights consistently less than $2 \mathrm{~m}$. Sea level was at or near this depth during the mid-Wisconsinan interstadial, and these ripplemarks are probably related to the passing of the floodwaters into the Atlantic Ocean.

\section{THE AMAZONIAN DEPOSITS}

A survey of the deposits cropping out along the rivers that cross southwestern Amazônia from the Andes to the Brazilian Shield demonstrate a continuity of deposition across the entire region. These deposits are described in CAMPBELL \& FRALEY (1984), CAMPBELL et al. (1985), CAMPBELL \& ROMERO (1987, in press), FRAILEY et al. (in press) and CAMPBEL et al. (in prep.).

In summary, alluvial and lacustrine deposits rest unconformably upon the underlying, unweathered or slightly weathered Tertiary deposits, with the basal deposit in many areas being a clay-pebble conglomerate, the Acre Conglomerate Member of the Madre de Dios Fm. This member often contains fossils of plants and animals reworked from the underlying Tertiary deposits, and it was probably formed by the megafiood that drained the Altiplano. Resting on this conglomerate, or directly upon the Tertiary deposits in its absence, are a series of two or more horizons that comprise a maximum total measured thickness of $45 \mathrm{~m}$ in Bolivia and $70 \mathrm{~m}$ in Peru. These horizons, comprising fine sands, silts and clays, were referred to as Units "A", "B" and "C" of the Madre de Dios (= Iñapari) Fm. by CAMPBELL \& FRAILEY (1984) and CAMPBEL et al. (1985).

Unit "A" comprises primarily fine sands, although in some areas it comprises mostly clays (CAMPBELL et al., 1985), and abundant channeling is present. It also contains many fossil tree trunks, several of which have yielded radiocarbon dates ranging from $>40,500$ years B.P. to $32,780 \pm 420$ years B.P., with two good dates at $36,500 \pm$. Unit " $A$ " is assumed to have been deposited shortly after the 
passage of the floodwaters, and if this is the case, then the megaflood occurred sometime prior to 36,600 years B.P., probably during the warmer portion of the world-wide mid-Wisconsinan interstadial, or 45,000 40,000 years B.P.

CAMPBEL et al. (1985:15) described Units "B" and "C" as lithologically more similar to each other than either was to Unit "A", and CAMPBEL \& ROMERO (in press) were uncertain as to whether the previously recognized Units " $B$ " and " $C$ " were, in fact, separate horizons. They suggested that perhaps Units " $\mathrm{B}$ " and " $\mathrm{C}$ " were different facies of a single member. A striking feature of these beds is the presence of pure clay, finely stratified or massive, often meters thick and often interfingering with well-sorted sand deposits. The composition and structure of these deposits led CAMPBEL \& ROMERO (1987, in press) to conclude that they were deposited in a deltaic environment within a large lake. FRALEY et al. (in press) arrived at a similar conclusion regarding deposits in western Brazil, and named the lake within which the deposits accumulated Lake Amazonas.

\section{LAKE AMAZONAS}

FRAILEY et al. (in press) proposed that Lake Amazonas formed in a tectonically driven system, whereby downwarping caused the formation of an interior continental basin in western Amazônia, within which sediments accumulated during the late Pleistocene. Isostatic adjustment was then to have caused the later uplift of the basin, bringing the deposits to their current elevation. They recognized that the lake may have extendend as far east as the Gurupá Horst at the eastern margin of the Amazon Basin, but suggested that it existed primarily in its western portions.

I disagree with this model of lake formation. In southeastern Peru it would require tectonic downwarping, the deposition of at least $70 \mathrm{~m}$ of fine sands, silts and clay, the subsequent elevation of these deposits to their present position and their dissection by alluvial processes, all in less than 40,000 years. Also, there is no visible evidence of tectonism in the late Pleistocene deposits.

I propose instead that a natural dam comprising the Belterra Clay was formed across the Amazon Basin just east of the confluence of the Rio Tapajos and Rio Amazonas, near Santarem by the flood from the Andes. Further, because the highest elevation deltaic deposits observed are about $260 \mathrm{~m}$ above sea level, I suggest that dam formed was at or above this elevation and that all areas of the Amazon Basin and contiguous areas below the $\mathbf{2 6 0} \mathrm{m}$ contour were covered by the lake. Outlets for this lake would have been the Rio Orinoco, into the Caribbean Sea, and the Rio Paraguay-Rio Parana, into the South Atlantic Ocean.

With this model, Unit "A" of the Madre de Dios Fm. formed as the lake was filling, while the upper Units " $\mathrm{B}$ " and " $\mathrm{C}$ " formed under different conditions at a time when the lake was at or near its peak 
extension. It is clear that the latter deposits were deposited within a vast, complex delta system, and thus represent facies of a single, large-scale depositional episode.

The delta system was of the "bird's foot" type, and delta fingers are clearly recognizable around the southern margins of the Amazon Basin in Bolivia. The similarity of topographic expression in that region to that of the Mississippi River Delta was noted by CAMPBEU et al. (1989). Also, the savannas in eastern Brazil noted by SOMBROEK (1966:219) were originally isolated lakes that persisted within the delta system and that were being infilled at varying rates when the lake drained. The savannas of southeastern Peru, such as those near the Rio Heath, have a similar origin, as do, perhaps, lowland savannas in the northern portions of the basin. These savannas cannot in any way be considered "refugia" of savannas that were supposedly widespread throughout Amazônia during glacial periods, as postulated by the Quaternary refuge theory.

Lake Amazonas began draining eastward at the end of the Pleistocene, probably assisted by a great influx of water as, first, the Andean glaciers began receding, and, later, increased precipitation may have resulted from a heightened monsoonal circulation in the early Holocene (KUTZBACH, 1981). The draining of Lake Amazonas is documented by evidence for a "freshwater spike" registered in deposits of the upper fan of the Amazon Cone (SHOWERS \& BEVIS, 1988), which indicates that a marked freshwater discharge out of the Amazon began at 13,500 years B.P., peaked at about 9,600 years B.P. and terminated about 6,000 years B.P.

Extensive flooding in Amazônia continued into the Holocene (CAMPBEL \& FRAILEY, 1984 and CAMPBEL et al., in prep.), and data documenting this, in combination with the newly recognized high Holocene lake levels in the Altiplano, demonstrate that the American tropics experienced a period of high precipitation at the end of the Pleistocene and during the early Holocene that corresponds to that observed in other tropical regions of the world (STREET \& GROVE, 1979).

\section{CONCLUSIONS AND RAMIFICATIONS}

This paper presents the case for the catastrophic draining of a large Altiplano paleolake during the mid-Wisconsinan interstadial, or about $45,000-40,000$ years B.P. The megaflood formed the Achocalla Valley of Bolivia, deposited the Acre Conglomerate Member of the Madre de Dios Fm. of southwestern Amazônia and the Belterra Clay of eastern axial Amazônia, and formed ripplemarks on the Amazon Cone. Lake Amazonas filled behind a dam formed by the Belterra Clay, and this lake rapidly accumulated sediments deposited within a large, complex "bird's foot" delta system. Draining of Lake Amazonas began at the end of the Pleistocene and continued throughout the early Holocene. Modern savannas within the basin occupy topographic lows that were not completely filled with deltaic sediments. 
The ramifications of the hypotheses presented here are multitudinous and range from understanding Andean icefields to the biogeography of Amazonian jungles, from the physics of megaflood hydrology to the colonization of the Altiplano and the Amazon Basin after the draining of gigantic lakes. Astonishing as it may be, both the Altiplano and lowland Amazônia are relatively new ecosystems, the latter probably still in a state of supersaturated equilibrium (CAMPBEL \& FRALEY, 1984).

\section{ACKNOWLEDGEMENTS}

Many indlviduals and institutions in several countries have made this work possible, and I am deeply grateful to all. I regret being unable to name each because of space limitations. Funding for field work that led to this paper came from NSF DEB 78-05861 and BSR 84-20012 and the National Geographic Society.

\section{REFERENCES}

ADAMS JR., C.E.; WELLS, J.T.; COLEMAN, J.M. (1986) Transverse bedformes on the Amazon Shelf. Continental Shelf Research, 6(1/2):175-187.

BAKER, V.R. \& NUMMEDAL, D. (1978) The channeled scabland: Planetary Geology Program. Washington, NASA. 186p.

CAMPBELL, K.E. (in press) Pleistocene glaciation on the Andean Altiplano of Bollvia. Boletin de Sociedad Geológica de Bolivia.

CAMPBELL, K.E. \& FRAILEY, C.D. (1984) Holocene flooding and species diversity in Southwestern Amazônia. Quaternary Research, 21:369-375.

CAMPBEL, K.E.; FRAILY, C.D.; ARRELANO-L, J. (1985) The geology of the Rio Beni: further evidence for Holocene flooding in Amazônia. Contributions in Science, 364:1-18.

CAMPBELL, K.E.; GRIEVE, R.A.F.; GARVIN, J.B.; PACHECO-Z, J. (1989) A newly discovered probable impact structure in Amazonian Bolvia. National Geographic Research, 5(4). 
CAMPBELL, K.E. \& ROMERO-P, L. (1987) Quaternary geology of Departamento de Madre de Dios. In: CONGRESO PERUANO DE GEOLOGIA, 6., Lima, 1987. Abstracts. Lima, Sociedad Geologica del Peru. p.89.

CAMPBEL, K.E. \& ROMERO-P., L (in press) The quaternary geology of Departamento de Madre de Dios, Peru. In: CONGRESSO PERUANO DE GEOLOGIA, 6., Lima, 1987. Proceedings. Lima, Sociedad Geological del Peru.

CLAPPERTON, C.M. (1981) Quaternary glaciations in the Cordillera Blanca, Peru and the Condillera Real Bolivia. Revista CIAF, 6:93-111.

CLAPPERTON, C.M. (1983) The glaciation of the Andes. Quaternary Science Reviews, (2):83-155.

COLINVAUX, P.A. (1987a) Amazon diversity in light of the paleoecological record. Quatemary Science Reviews, 6(2):93-114.

COLNVAUX, P.A. (1987b) Environmental history of the Amazon Basin. Quaternary of South America and Antarctic Peninsula, 5:223-237.

DOBROVOLNY, E. (1962) Geologia del Valle de La Paz. Boletin Departamento Nacional de Geologia. Ministerio de Minas y Petroleo, 3:1-153.

DOBROVOLNY, E. (1968) A postglacial mudflow of large volume in the la Paz Valley, Bolivia. United States Geological Survey Professional Paper, 600-C:130-134.

DUELLMAN, W. (1979) The South American Herpetofauna: its origin, evolution and dispersal. University of Kansas, Museum of Natural History Monograph $n^{e} 7$.

FRAILEY, C.D.; LAVINA, E.; RANCY, A.; SOUZA FILHO, J.P. (in press) A proposed Pleistocene/Holocene lake in the Amazon basin and its significance to Amazonian geology and biogeography. Acta Amazonica.

HAFFER, J. (1969) Speciation in Amazonian forest birds. Science, 165:131-137.

HASTENRATH, S. \& KUTZBACH, J.E. (1985) Late Pleistocene climate and water budget of the South 
American Altiplano. Quaternary Research, 24:249-256.

KUTZBACH, J.E. (1981) Monsoon climate of the early Holocene: climate experiment with the earth's orbital parameters for 9,000 years ago. Science, 214:59-61.

LAVENU, A.; FORNARI, M.; SEBRIER, M. (1984) Existence de deux nouveaux episodes lacustres quaternaires dans l'Altiplano peruvo-bolivien. Cahiers O.R.S.T.O.M. Série Géoiogie, 14:103-114.

MOON, H.P. (1939) The geology and physiography of the Altiplano of Peru and Bolivia. Transactions of the Linnean Society of London, Ser.3, 1:27-43.

PLAFKER, G. (1964) Oriented lake and lineaments of Northeastern Bolivia. Bulletin Geological Society of America, 75(6):503-522.

PRANCE, G.T. (1982) Biological diversification in the tropics. New York, Columbia University Press. $714 p$.

SHOWERS, J.W. \& BEVIS, M. (1988) Amazon cone isotopic stratigraphy: evidence for the source of the tropical freshwater spike. Palaeogeography, Palaeoclimatology, Palaeoecology, 64:189-199.

SIMPSON, G.G \& PAULA-COUTO, C. (1981) Fossil mammals from the Cenozoic of Acre, Brazil III Pleistocene Edentata, Pilosa, Proboscidea, Sirenia, Perissodactyla and Artiodactyla. Iheringia, Série Geologia, (6):11-73.

SOMBROEK, W.G. (1966) Amazonian soils: a reconnaissance of the soils of the Brazilian Amazon region. Wageningen, Centre for Agricultural Publications and Documentation. 292p.

STREET, F.A. \& GROVE, A.T. (1979) Global maps of lake - level fluctuations since 30,000 years B.P. Quaternary Research, 12:83-118.

TRUCKENBRODT, W. \& KOTSCHOUBEY, B. (1981) Argila de Belterra - cobertura terciária das bauxitas amazônicas. Revista Brasileira de Geociências, 11(3):203-208.

WHITMORE, T.C. \& PRANCE, G.T. (1987) Biogeography and quatemary history in tropical America. Oxford, Clarendon Press. 214p. 
WIRRMANN, D. \& ALMEIDA, LF.O. (1987) Low Holocene level $(7,700$ to 3,650 years ago) of Lake Titicaca (Bolivia). Palaeogeography, Palaeoclimatology, Palaeoecology, 59:(4):315-323. 